Article

\title{
Environmental Regulation Intensity, Foreign Direct Investment, and Green Technology Spillover-An Empirical Study
}

\author{
Jiangfeng Hu, Zhao Wang, Qinghua Huang and Xiaoqin Zhang * \\ School of Economics and Management, Southwest University, Chongqing 400715, China; \\ leisure@email.swu.edu.cn (J.H.); wz777@163.com (Z.W.); hqh@swu.edu.cn (Q.H.) \\ * Correspondence: zxq0113@email.swu.edu.cn
}

Received: 3 April 2019; Accepted: 1 May 2019; Published: 14 May 2019

check for updates

\begin{abstract}
Many researchers have studied the relationships among heterogeneous foreign direct investment (FDI), environmental regulation, and green total factor productivity. However, no research has been done on how different types of FDI can result in green technology spillover under different levels of environmental regulation intensity. To address this research gap, in this paper, we build a static linear panel model, a static panel threshold model, and a dynamic panel threshold model to investigate the environmental regulatory threshold effect of labor-based FDI and capital-based FDI in terms of their green technology spillover. Based on the measurement of green total factor productivity (GTFP) of 36 industry sectors in China from 2003 to 2015, we first compare the threshold effects of environmental regulation on green technology spillover between labor-based FDI and capital-based FDI with a static linear model and a static threshold model. The results show that environmental regulation is unable to significantly promote the green technology spillover of labor-based FDI. However, intensifying environmental regulation can reduce the negative impact of labor-based FDI on GTFP. The effect of environmental regulation on green technology spillover of capital-based FDI is more complex. In the static linear model, environmental regulation can significantly promote the green technology spillover of capital-based FDI. In the static threshold model, the green technology spillover of capital-based FDI exists only when the environmental regulation intensity is sufficiently low or sufficiently high. Finally, the dynamic threshold model is adopted for robustness check. The results show when the environmental regulation intensity is higher than a threshold, both types of FDI can indeed result in green technology spillover. In short, our results prove that to ensure that FDI results in green technology spillover, it is necessary to continue to strengthen environmental regulation.
\end{abstract}

Keywords: heterogeneous FDI; green technology spillover; green total factor productivity; environmental regulation intensity; threshold effect

\section{Introduction}

FDI has become an important thrust for the economic development of many developing countries [1,2]. For example, China's FDI rode from 430 million dollars ( $0.21 \%$ of GDP) in 1982 to 144 billion dollars (12\% of GDP) in 2017. However, with the influx of foreign capital, the ecological environment may deteriorate. Considering the relatively relaxed environmental regulations in many developing countries, developing countries can become the 'pollution haven' of multinational corporations. The reason is as follows. According to the theory of resource endowment, because of the comparative advantage of rich human capital and relatively loose environmental control in developing countries, multinational corporations will transfer pollution intensive production to developing countries [3-5]. Although this transfer can boost the productivity of a host country, it also causes serious environmental pollution $[1,6-8]$. 
Moreover, in order to attract foreign investment, developing countries or regions may take the initiative to reduce environmental regulation standards, namely "race to bottom" [9,10]. As a result, developing countries would gradually become a "pollution haven" of developed countries [11-13].

However, some scholars argue that when multinationals enter developing countries with lower environmental standards, they bring production standards and technologies that are more environmentally friendly than those available from the host country's enterprises [14]. Through the "demonstration effect", it has a positive impact on the environmental protection of the host country. This is the "pollution halo hypothesis" [15].

The above two conflicting views indicate that FDI's technology spillovers to the host country may improve or damage the environmental of a host developing country. Hu et al. [3], Cai and Lu et al. [13], and Tang [16] respectively focus on foreign capital characteristics of source, motivation, and factor dependence. Some scholars have studied the impact of environmental regulation on FDI. They argue that strict environmental regulation can not only hinder the entry of FDI resulting in heavy pollution [4,13], but also promote FDI resulting in green technology spillover [3]. However, a few empirical studies have shown that strengthening environmental regulation can increase the burden on enterprises and cause productivity losses [17]. In particular, Johnstone et al. [18], Wang and Shen [19], and Xie et al. [20] argue that the intensity of environmental regulation should not be too high. If the intensity exceeds the maximum level that enterprises or industries can bear, it will cause damage to competitiveness. Hence, there has a reasonable range of environmental regulation intensity. However, most studies focus on the impact of environmental regulation intensity on productivity. There is a lack of research on the impact of environmental regulation intensity on FDI's possible technology spillover effect. In this paper, we make a major contribution by filling this research gap. Specifically, we aim to answer the following questions: is there an optimal range of environmental regulation intensity for FDI to result in green technology spillover? Considering the heterogeneity of FDI, how should the environmental regulation intensity be set? By answering these questions, we show FDI can improve or damage the host country's ecological environment. Furthermore, our research results can provide reference for developing countries to design appropriate environmental policies so that FDI can result in green technology spillover.

Compared with the existing literature, the possible marginal contributions of this paper can be summarized as follows: (1) Many existing studies focus on the relationship between environmental regulation, FDI, and GTFP, but lack the impact of changes in environmental regulation intensity on FDI green technology spillover effect. This paper uses the interaction term between environmental regulation and FDI to clarify that environmental regulation has a moderating effect on FDI green technology spillover effect. Furthermore, the static and dynamic panel threshold models are used to determine the environmental regulation intensity that induces FDI to play a positive role in green technology spillover. (2) Although many studies have recognized that different types of FDI have different technology spillover effects, the research on the impact of environmental regulation intensity on green technology spillover effects of heterogeneous FDI still needs to be supplemented. According to the dependence of FDI on labor and capital share in the host industry, this paper divides FDI into labor-based FDI and capital-based FDI, and then determines the optimal environmental regulation intensity to induce two types of FDI to exert positive green technology spillover effects through panel threshold model.

The rest of the paper is structured as follows. Section 2 provides a literature review. Section 3 proposes the empirical model. Section 4 describes the data and variables. Section 5 details the empirical results and analysis. Finally, Section 6 summarizes the conclusions of this paper.

\section{Literature Review}

Many studies have that FDI is heterogeneous, so the effect of FDI on a host country's economy and environment can be significantly different. For example, China's foreign investors are from firms in Hong Kong, Macao, and Taiwan (HMT), or in other countries (mainly the OECE countries). 
Compared with the non-HMT firms, the HMT firms tend to be more labor intensive and produce closer substitutes to products of Chinese domestic firms. They can squeeze the domestic firms out of the market, which may not improve productivity [21]. Furthermore, many HTM firms are attracted by the weak environmental standards [22]. Therefore, FDI from HMT firms can have a negative impact on the environment [13]. Markusen and Venables [23] divide FDI into vertical FDI and horizontal FDI. They suggest that the motivation for horizontal FDI to enter developing countries is mainly to occupy the host country's local market, while vertical FDI is mainly to take advantage of the cheaper production factors (labor and resources) of the host country to produce products for export to foreign markets. Tang [16] further study the impact of vertical FDI and horizontal FDI on the host country's environment and find that vertical FDI has a greater negative impact on the environmental quality of the host country than horizontal FDI. Hu et al. [3] divide FDI into labor-based FDI and capital-based FDI based on the dependence of FDI on labor and capital share in the host industry. In addition, some scholars have classified FDI in China into Sino-foreign joint ventures and wholly foreign-owned enterprises based on the ownership structure. They show that foreign-owned enterprises have stronger technology spillover effects [24,25].

With the increase of environmental regulation barriers around the world, more and more scholars have studied the impact of environmental regulation on FDI. According to Broner et al. [26], environmental regulations are subprime trade barriers and a source of comparative advantage for a country. Therefore, changes in environmental regulation will impact on FDI's entry and exit $[4,27]$. However, there is no definitive evidence in the literature that a host country's strengthening of environmental regulation will result in losing its comparative advantage [28] and hindering the entry of foreign companies [29], which in turn leads to productivity decline [17]. On the contrary, tightening environmental regulation in developing countries not only squeeze out polluting FDI firms [13], but also promote the inflow of environmentally-friendly FDI firms [30,31]. Therefore, FDI with different characteristics has different responses to environmental regulation. Tang [16] argues that export-oriented FDI is more sensitive to local environmental regulations than local market-oriented FDI, because the level of environmental regulation in the host country will only significantly increase the relative cost of the former. In addition, $\mathrm{Hu}$ et al. [3] also find that with the strengthening of environmental regulation, FDI that initially damaged the host country's ecological environment may change and improve the environment. Other relevant studies also show that the rationality of environmental regulation is an important prerequisite for achieving a 'win-win' outcome for the economy and the environment [32]. Johnstone et al. [18], Wang and Shen [19], Xie and Yuan et al. [20] study the relationships between environmental regulation and productivity. They argue that the intensity of environmental regulation should be set within a reasonable interval. If the intensity exceeds the maximum limit that the industry or firms can bear, it will have a negative impact on productivity. However, these studies focus on the direct impact of environmental regulation intensity on productivity without considering the impact of environmental regulation intensity on the possible green technology spillover of heterogeneous FDI types. Although Hu et al. [3] consider the green technology spillover effect of FDI under low and high levels of environmental regulation intensity, the study employs the median to classify the intensity of environmental regulation, which is subjective.

Studies have been done to regress FDI total factor productivity on the technology spillover effect of FDI on host countries [21,33]. However, this paper differs by considering the unexpected output when calculating the green total factor productivity. In terms of measuring green total factor productivity, researchers commonly use the non-radial slacks-based measure (SBM) function and Malmquist-Luenberger (ML) productivity index. There are two potential shortcomings in the traditional ML index. First, the total factor productivity measured by the ML index does not have a multiplicative property. Only the short-term fluctuation analysis of production efficiency in the adjacent period can be performed, but the long-term growth trend of production efficiency cannot be observed, which may result in the emergence of 'technical regression', which is obviously unrealistic. Second, the mixed direction of SBM function, reduced output, and reduced output of undesired 
output may lead to no feasible solution. On the other hand, the Global Malmquist-Luenberger (GML) index is based on a set of production possibilities over the full-time horizon of all decision-making units. As a result, the GML index can avoid the drawbacks of no feasible solutions. Furthermore, the continuous production frontier can also avoid the phenomenon of "technical regression" [34]. In empirical applications, Wang and Shen [19] adopt the GML index to measure China's industrial green productivity from 2000 to 2012 based on the static threshold model. They examine the nonlinear relationship between environmental regulation intensity and green total factor productivity and show that there are three thresholds for the impact of environmental regulation on green productivity.

However, in the literature, research is still lacking on the technology spillover effect of heterogeneous FDI under different levels of environmental regulation intensity. In view of this, this paper chooses chemical oxygen demand, ammonia nitrogen, and $\mathrm{SO}_{2}$ and smoke (powder) dust emissions as unexpected output, and employs the SBM function and GML index to calculate the green total factor productivity. Furthermore, this paper combines static linear panel model, static panel threshold model and dynamic panel threshold model and explores the environmental regulatory threshold effect of heterogeneous FDI green technology spillover.

\section{Methods}

\subsection{Theoretical Model}

This paper draws on the knowledge spillover model of Bretschger et al. [35] and Aldieri et al. [36] and consider only two different types of firms in the market, namely foreign firms $(f)$ and domestic firms $(l)$. The level of foreign technology is higher than that of domestic firms. The basic production function is

$$
\mathrm{Y}=\mathrm{Y}\left(Y_{f}, Y_{l}, \mathrm{ER}\right)
$$

where $Y$ is the total output, $Y_{f}$ is the output of FDI firms, and $Y_{l}$ is the output of local firms. Assume that FDI firms and local firms produce goods in the same capital and labor assemble and the difference between the two is only at the technical level. Therefore, Equation (1) can be transformed to

$$
\mathrm{Y}=\mathrm{A}\left(A_{f}, A_{l}, \mathrm{ER}\right) F(K, L)
$$

where $A_{f}$ is the technical level of the FDI firms, $A_{l}$ is the technical level of the local firms of the host country, and $F(K, L)$ is the production function of the specific factor combination. According to the definition of total factor productivity, Equation (2) can be transformed into

$$
\mathrm{GML}=\mathrm{A}\left(A_{f}, A_{l}, \mathrm{ER}\right)
$$

where GML is the global total factor productivity considering unexpected outputs. The technical level of the local firms in the host country is mainly determined by the technical level of the FDI firms. The technical level of the FDI firms mainly comes from research and development and the technology spillover of the domestic firms. Thus,

$$
\begin{gathered}
A_{l}=A_{l}\left(A_{f}\right) \\
A_{f}=A_{f}\left(B_{f} ; B_{f}^{S}\right)
\end{gathered}
$$

where $B_{f}$ is the self-owned technology of FDI firms and $B_{f}^{s}$ is affected by the technology spillover effect of the parent company.

$$
\begin{gathered}
B_{f}=B_{f}(\chi) \\
B_{f}^{s}=B_{f}^{s}\left(\chi^{s}\right)
\end{gathered}
$$


where $\chi$ is the ability to transform the results of independent research and development, and $\chi^{S}$ is the learning ability, which is determined as

$$
\begin{gathered}
\chi=\sum_{i=1}^{n} a_{i} x_{i} \\
\chi^{s}=\sum_{j=1}^{n s} a_{j} x_{j}^{s}
\end{gathered}
$$

where $x_{i}$ is the research and development investment of the $i$ th industry, $a_{i}$ is the conversion coefficient of research and development, $x_{j}^{s}$ is the positive externality of the R\&D investment in the ith industry, and $a_{j}$ is the conversion coefficient. Based on Equations (3)-(9), we can have

$$
\begin{aligned}
\mathrm{dGML}= & \frac{\partial A}{\partial E R} d E R+\frac{\partial A}{\partial A_{f}}\left\{\frac{\partial A_{f}}{\partial B_{f}} \frac{\partial B_{f}}{\partial \chi}\left[\sum_{i=1}^{n} a_{i} d x_{i}\right]+\frac{\partial A_{f}}{\partial B_{f}^{s}} \frac{\partial B_{f}^{s}}{\partial \chi}\left[\sum_{i=1}^{n} a_{i} d x_{j}^{s}\right]\right. \\
& \frac{\partial A}{\partial A_{l}} \frac{\partial A_{l}}{\partial A_{f}}\left\{\frac{\partial A_{f}}{\partial B_{f}} \frac{\partial B_{f}}{\partial \chi}\left[\sum_{i=1}^{n} a_{i} d x_{i}\right]+\frac{\partial A_{f}}{\partial B_{f}^{s}} \frac{\partial B_{f}^{s}}{\partial \chi}\left[\sum_{i=1}^{n} a_{i} d x_{j}^{s}\right]\right.
\end{aligned}
$$

It can be seen from Equation (10) that the green total factor productivity (dGML) is affected by environmental regulation (dER), R\&D investment $\left(d x_{i}\right)$, and foreign technology spillover $\left(d x_{j}^{s}\right)$.

\subsection{Econometric Model}

Based on theoretical model above, we can obtain the empirical model of this paper as

$$
\operatorname{lnGML} L_{i, t}=\alpha_{0}+\alpha_{1} \operatorname{lnFDI}_{i, t}+\ln E R_{i, t}+\beta \operatorname{Control}_{i, t}+\mu_{\mathrm{i}}+\varepsilon_{\mathrm{i}, \mathrm{t}}
$$

where $\ln \mathrm{FDI}_{\mathrm{i}, \mathrm{t}}$ stands for labor-based FDI $\left(\ln \mathrm{FDIl}_{\mathrm{i}, \mathrm{t}}\right)$ and capital-based FDI $\left(\ln \mathrm{FDIk}_{\mathrm{i}, \mathrm{t}}\right)$, respectively; Control $i_{i, t}$ is the control independent variable group, including $R \& D$ intensity $\left(\ln R D_{i, t}\right)$, foreign trade openness $\left(\operatorname{lnExout} \mathrm{i}_{\mathrm{i}, \mathrm{t}}\right)$, per capita capital stock $\left(\operatorname{lnCONS}_{\mathrm{i}, \mathrm{t}}\right)$, and energy production efficiency $\left(\operatorname{lnEP_{i,t}}\right)$; $\mu_{\mathrm{i}}$ is the industry individual fixed effect that does not change with time; and $\varepsilon_{\mathrm{i}, \mathrm{t}}$ is a random disturbance term. In Equation (11), the natural logarithm processing of the variables is taken, so that the heteroscedasticity can be effectively avoided. In addition, according to Greaney et al. [27] and Zugravu-Soilita [30], there is an interactive interaction between FDI and environmental regulation. Specifically, the inflow of FDI can drive a host country to strengthen its environmental regulation. This can in turn raise the environmental regulation threshold for FDI screening. To test the impact of the interaction between FDI and environmental regulation on green total factor productivity, we add the $\ln F \mathrm{II}_{\mathrm{i}, \mathrm{t}} \times \ln E R_{i, t}$ interaction term and the have the model

$$
\operatorname{lnGML} \mathrm{i}_{\mathrm{i}, \mathrm{t}}=\alpha_{0}+\alpha_{1} \operatorname{lnFDI}_{\mathrm{i}, \mathrm{t}}+\alpha_{2} \ln E R_{i, t}+\alpha_{3} \ln \mathrm{FDI}_{\mathrm{i}, \mathrm{t}} \times \ln E R_{i t}+\beta \operatorname{Control}_{\mathrm{i}, \mathrm{t}}+\mu_{\mathrm{i}}+\varepsilon_{\mathrm{i}, \mathrm{t}}
$$

However, it is still impossible to examine what level of environmental regulation intensity can promote FDI to bring green technology spillover to the host country. To solve this problem, we adopt the panel threshold model proposed by Hansen [37] to empirically test whether the green spillover effect of FDI is affected by environmental regulation intensity. We have the model

$$
\begin{gathered}
\operatorname{lnGML} \mathrm{i}_{\mathrm{i}, \mathrm{t}}=\alpha_{1} \operatorname{lnFDI}_{\mathrm{i}, \mathrm{t}} \mathrm{I}\left(\operatorname{lnER}_{\mathrm{i}, \mathrm{t}} \leq \theta_{1}\right)+\alpha_{2} \operatorname{lnFDI}_{\mathrm{i}, \mathrm{I}} \mathrm{I}\left(\theta_{1}<\operatorname{lnER} \mathrm{R}_{\mathrm{i}, \mathrm{t}} \leq \theta_{2}\right)+\ldots \\
+\alpha_{\mathrm{n}} \ln \operatorname{FDI}_{\mathrm{i}, \mathrm{I}}\left(\theta_{\mathrm{n}-1}<\operatorname{lnER} \mathrm{in}_{\mathrm{i}, \mathrm{t}} \leq \theta_{\mathrm{n}}\right)+\alpha_{\mathrm{n}+1} \ln \operatorname{lnDI}_{\mathrm{i}, \mathrm{t}} \mathrm{I}\left(\operatorname{lnER}_{\mathrm{i}, \mathrm{t}}>\theta_{1}\right)+\beta \text { Control }_{\mathrm{i}, \mathrm{t}}+\mu_{\mathrm{i}}+\varepsilon_{\mathrm{i}, \mathrm{t}}
\end{gathered}
$$

where $\theta_{1}, \theta_{2}, \ldots \theta_{\mathrm{n}}$ are $n$ different levels of threshold. The introduction and estimation methods of the panel threshold model have been detailed in the literature such as Xie et al. [20] and Hansen [37]. Finally, to ensure the robustness of our empirical results and avoid the endogeneity issue, we add the hysteresis term $\operatorname{lnGML} \mathrm{L}_{\mathrm{i}, \mathrm{t}-1}$ of the green total factor productivity and estimate the model by the GMM 
method. In this way, the static panel threshold model is extended to the dynamic panel threshold model as

$$
\begin{aligned}
& \left.\operatorname{lnGML} L_{i, t}=\operatorname{lnGML} L_{i, t-1}+\alpha_{1} \operatorname{lnFDI}_{i, t} I_{(}\left(\operatorname{lnER}_{i, t} \leq \theta_{1}\right)+\alpha_{2} \operatorname{lnFDI}_{i t} \mathrm{I}_{\left(\theta_{1}\right.}<\operatorname{lnER} R_{i, t} \leq \theta_{2}\right)+\ldots \\
& +\alpha_{\mathrm{n}} \operatorname{lnFDI}_{\mathrm{i}, \mathrm{t}} \mathrm{I}\left(\theta_{\mathrm{n}-1}<\ln \mathrm{ln}_{\mathrm{i}, \mathrm{t}} \leq \theta_{\mathrm{n}}\right)+\alpha_{\mathrm{n}+1} \operatorname{lnFDI}_{\mathrm{i}, \mathrm{t}} \mathrm{I}\left(\operatorname{lnER}_{\mathrm{i}, \mathrm{t}}>\theta_{1}\right)+\beta \operatorname{Control}_{\mathrm{i}, \mathrm{t}}+\mu_{\mathrm{i}}+\varepsilon_{\mathrm{i}, \mathrm{t}}
\end{aligned}
$$

\section{Data and Variables}

\subsection{Data and Processing}

This paper uses China Industrial Economy Statistical Yearbook, China Energy Statistical Yearbook and China Environment Statistical Yearbook to quantify the relevant indicators. In view of the inconsistency of certain categories of industries before and after 2012 and the absence of some data, this paper also processes the data as follows.

According to the classification method of the National Bureau of Statistics proposed in 2011, China's industry included 41 sectors after 2012. The following changes occurred: mining auxiliary activities are spun off from the oil and gas mining industry become a separate industry. The rubber products and plastic products industries are merged into the rubber and clinker products industry. Transportation equipment manufacturing industry is split into automotive manufacturing and railway shipping, aviation, and other transportation equipment manufacturing. The metal equipment machinery and equipment repair industry are stripped from the manufacturing industry that used metals as raw materials to become an industry alone.

To maintain data authenticity, this paper categorized and divided the subdivided classes of some industrial sectors. First, the rubber product industry and plastic product industry before 2012 are merged into the rubber and clinker products industry. Second, the reorganization of mining assistance activities and oil and gas exploration industries after 2012 into the oil and gas industry, the automobile industry and railway, ship, and other transportation equipment are merged into the transportation equipment industry, and the metal product machinery and equipment repair industry are divided and re-integrated into the industry using metal as raw materials according to the proportion of the indicators of the year. Finally, due to the relatively small sizes of other mining, other manufacturing, and waste product recycling industries, these three are merged into other industries. In the end, the panel data of 36 industrial sectors from 2003 to 2015 are obtained. Furthermore, due to the lack of employment in the industrial sector segmentation in 2012, this article adopts a linear fitting method to fill in the missing data.

\subsection{Variables Selection and Definition}

\subsubsection{Green Total Factor Productivity}

In this paper, we consider the SBM directional distance function of unanticipated outputs according to the definition proposed in Fukuyama and Weber [38]. We combine the Global Malmquist-Luenberger (GML) index proposed by Oh [34] to measure the green total factor productivity of 36 sectors of Chinese industry from 2003 to 2015. The specific calculation method can be found in Wang and Shen [19]. Before measuring the green total factor productivity in various sectors, it is also necessary to construct variables related to expected output, unanticipated output, and factor input.

As for expected output, since the total industrial output value is no longer published after 2012, this paper follows Zhao et al. [39] and selects the industrial sales value that is close to the industrial output value to obtain the expected output and converts it at a constant price in 1990. As for unexpected output, considering that China's industrial pollution control costs only include wastewater treatment costs and waste gas treatment costs, this paper selects chemical oxygen demand, ammonia nitrogen, $\mathrm{SO}_{2}$, and smoke (powder) dust emissions as unanticipated outputs. As for factor input, considering the availability and quality of data, this paper uses the method proposed in $\mathrm{Hu}$ and Wang [3] to calculate 
the current capital stock of each industry. As for labor capital investment, due to the inability to obtain labor time in various industries, this paper uses the average number of employees in various industries in the "China Industrial Statistical Yearbook" instead of human capital investment. As for energy input, this paper uses the total energy consumption of various industries as an energy input indicator.

\subsubsection{Core Independent Variables}

(1) Environmental Regulation (ER)

In 2018, China began to impose an environmental tax on enterprises. However, prior to this, there was no standard for measuring the intensity of environmental regulation. Scholars measure environmental regulation intensity using a variety of methods such as the number of environmental regulations [40], the ratio of pollution control costs to industrial output or operating income [19,41], the pollution control investment in total cost or production value [42], and the pollution emission density [28]. Considering wastewater (COD, ammonia nitrogen) and exhaust gas $\left(\mathrm{SO}_{2}\right.$, smoke/dust) are the unexpected output when measuring the total factor productivity, this paper calculates the weighted average sum of the wastewater and waste gas treatment costs of various sectors. The weight of each is the proportion of the input of wastewater or exhaust gas treatment facilities.

(2) Foreign Direct Investment (FDI)

The impact of different types of FDI on the economy and the environment of a host country can be quite different. This means that FDI cannot be measured only by comprehensive indicators such as the scale of investment and the number of new foreign-funded enterprises [5]. To classify FDI, scholars have proposed different methods. Lin et al. [21] divided FDI into foreign investment from Hong Kong, Macau, and Taiwan, and foreign investment other regions and countries. Javorcik and Spatareanu [33] classify FDI as from the European Union or from the United States. Beugelsdij et al. [43] use FDI from different foreign-invested enterprises in different markets to measure the FDI of different entry motives. The horizontal FDI is measured by the sales share of the foreign-funded enterprises in the Chinese market, and the vertical FDI is measured by the export sales of the foreign-funded enterprises. In Cai et al. [13], FDI is divided into two categories: countries with high or low environmental regulation barriers. However, most studies focus on the national or enterprise level, but not at the industry level. Furthermore, industries are commonly categorized into labor-intensive industries and capital-intensive industries. Hence, FDI can be categorized into labor-based FDI (FDIl) and capital-based FDI (FDIk).

\subsubsection{Control Variables}

We employ a few control variables. The first is R\&D intensity (RD). In general, more R\&D investment is more conducive to technological progress, and thus the productivity is higher [44]. Wang and Shen [19] measures the R\&D intensity of each industry by the ratio of R\&D expenditures to fixed asset investment in various industries. The second control variable is the exemption of foreign trade (Exout). Developing countries often produce and export pollution-intensive products to developed countries. Hence, in the long run, their product structures may be locked in pollution-type $[4,5,28]$. This paper draws on the method in Rubashkina et al. [45] to measure the index of foreign trade openness by the ratio of the export value of industrial industry to the sales value of industrial industry. The third is energy production efficiency (EP). Some industries may consume a large amount of resources, some of them often non-renewable. Energy productivity is a direct reflection of the energy consumption and pollution emission characteristics of various industries. This paper adopts the method of Wang and Shen [19], which is expressed by the ratio of the sales value of each industry to the total energy consumption. The fourth control variable is per capita capital stock (CONS). The per capita capital stock is composed of input factors of various industries to reflect the height of each industry. This paper adopts the method in Hu and Wang et al. [3] and Wang and Shen [19] to use the ratio of net fixed assets to average number of employees to measure the per capita capital stock of each industry. The variables and their definitions are summarized in Table 1. 
Table 1. Variables and definitions.

\begin{tabular}{|c|c|c|}
\hline Variable & Name & Definition \\
\hline \multirow{3}{*}{ GML } & Expected output & Industrial sales value based on 1990 \\
\hline & Unexpected output & $\begin{array}{l}\text { Chemical oxygen demand, ammonia nitrogen, } \mathrm{SO}_{2} \text {, } \\
\text { smoke (powder) dust emissions }\end{array}$ \\
\hline & Factor input & Capital stock, employment, and energy consumption \\
\hline \multirow{2}{*}{$\begin{array}{l}\text { Core independent } \\
\text { variable }\end{array}$} & Environmental regulation (ER) & $\begin{array}{l}\text { Weighted average sum of wastewater and waste gas } \\
\text { treatment costs in various sectors }\end{array}$ \\
\hline & Foreign direct investment (FDI) & Labor-based FDI(FDIl)and capital-based FDI(FDIk) \\
\hline \multirow{4}{*}{ Control variable } & R\&D intensity (RD) & Ratio of R\&D expenditure to fixed asset investment \\
\hline & Trade openness (Exout) & $\begin{array}{l}\text { Ratio of export value of industrial industry to sales value } \\
\text { of industrial industry }\end{array}$ \\
\hline & Energy production efficiency (EP) & $\begin{array}{c}\text { Ratio of total industrial output value to total industrial } \\
\text { energy consumption }\end{array}$ \\
\hline & Per capita capital stock (CONS) & Ratio of net fixed assets to average number of employees \\
\hline
\end{tabular}

\section{Results and Discussion}

\subsection{Benchmark Regression Analysis}

Table 2 is the regression results of the benchmark linear model. Model (1a) and model (2a) are the effects of labor-based FDI and capital-based FDI on green total factor productivity, respectively. Model (3a) and model (4a) are the regression results after incorporating the environmental regulation and FDI interaction items. In order to ensure the robustness of the regression results, this paper clusters the industry code (Cluster) and uses Robust to adjust the standard error.

Table 2. Estimation results of the static panel linear model.

\begin{tabular}{|c|c|c|c|c|}
\hline \multirow{2}{*}{ Variable } & Labor-Based FDI & Capital-Based FDI & Labor-Based FDI & Capital-Based FDI \\
\hline & (1a) & (2a) & (3a) & (4a) \\
\hline $\operatorname{lnFDI}$ & $\begin{array}{c}-0.0429 * * \\
(-3.01)\end{array}$ & $\begin{array}{l}-0.028 \\
(-1.54)\end{array}$ & $\begin{array}{c}-0.0652 \text { ** } \\
(-2.43)\end{array}$ & $\begin{array}{c}-0.0482 * \\
(-1.88)\end{array}$ \\
\hline $\operatorname{lnFDI}{ }^{*} \ln E R$ & & & $\begin{array}{c}0.0104 \\
(1.43)\end{array}$ & $\begin{array}{c}0.00995^{*} \\
(1.77)\end{array}$ \\
\hline $\operatorname{lnER}$ & $\begin{array}{c}0.00604 \\
(0.59)\end{array}$ & $\begin{array}{c}0.00637 \\
(0.62)\end{array}$ & $\begin{array}{c}0.0249 * \\
(2.02)\end{array}$ & $\begin{array}{l}0.0252 * * \\
(2.17)\end{array}$ \\
\hline $\ln R D$ & $\begin{array}{c}0.0257^{*} \\
(1.83)\end{array}$ & $\begin{array}{c}0.0186 \\
(1.15)\end{array}$ & $\begin{array}{c}0.0275^{*} \\
(1.95)\end{array}$ & $\begin{array}{c}0.0225 \\
(1.38)\end{array}$ \\
\hline $\operatorname{lnExout}$ & $\begin{array}{c}-0.0305^{* *} \\
(-2.75)\end{array}$ & $\begin{array}{c}-0.0267^{* *} \\
(-2.90)\end{array}$ & $\begin{array}{c}-0.0238^{*} \\
(-1.93)\end{array}$ & $\begin{array}{c}-0.0192 \\
(-1.67)\end{array}$ \\
\hline $\operatorname{lnCONS}$ & $\begin{array}{c}-0.0814^{* * *} \\
(-5.88)\end{array}$ & $\begin{array}{c}-0.0779 * * * \\
(-5.78)\end{array}$ & $\begin{array}{c}-0.0786^{* * *} \\
(-5.55)\end{array}$ & $\begin{array}{c}-0.0756^{* * *} \\
(-5.42)\end{array}$ \\
\hline $\operatorname{lnEP}$ & $\begin{array}{c}0.0577^{* * *} \\
(4.22)\end{array}$ & $\begin{array}{c}0.0482 * * * \\
(4.30)\end{array}$ & $\begin{array}{c}0.0563^{* * *} \\
(3.87)\end{array}$ & $\begin{array}{c}0.0477^{* * *} \\
(4.30)\end{array}$ \\
\hline Sample & 468 & 468 & 468 & 468 \\
\hline$R^{2}$ & 0.095 & 0.087 & 0.102 & 0.094 \\
\hline
\end{tabular}

Note: The value in parentheses is the value of $\mathrm{t}$. Among them: ${ }^{*}, * * * * *$ respectively indicate that the parameters are estimated to pass the statistical significance test at $10 \%, 5 \%$, and $1 \%$.

In model (1a) and model (2a), the labor-based FDI and capital-based FDI have negative impact on green total factor productivity. However, only the labor-based FDI spillover is significant at the 5\% significance level. This confirms that the 'pollution haven' effect exists for labor-based FDI. This is because labor-intensive industries have the characteristics of cleaner production Cole and Elliott [12], and labor-based FDI can bring green technology spillover to a host country by improving the quality of human capital [30]. However, labor-intensive industries tend to have relatively weak environmental regulations [19]. It is difficult to stimulate enterprises to carry out technological 
innovation and management innovation, which is not conducive to the improvement of the green total factor productivity [3]. In comparison, capital-intensive industries may have a high degree of pollution, which is indicated from the negative regression coefficient of lnCONS. Many scholars argue that capital-based FDI is attracted by weaker environmental regulations of a host country. However, Cole and Elliott [12] pointed out that the comparative advantage brought about by factor endowments can indeed attract capital-based FDI into capital-intensive industries in developing countries. However, at the same time, the environmental regulation of capital-intensive industries is relatively tighter. Hence, it also has a restraining the potential pollution from capital-based FDI. Consequently, the impact of capital-based FDI on the green total elements of a host country can be uncertain.

Interestingly, in the models with the interaction item between FDI and environmental regulation, model (3a) and model (4a), the interaction between labor-based FDI and environmental regulation and the interaction between capital-based FDI and environmental regulation are positive. This means that the relationship between environmental regulation and the positive interaction of FDI exists. However, only the interaction between capital-based FDI and environmental regulation is significant at the $10 \%$ significance level. It is noteworthy that the coefficients of environmental regulation variables (lnER) not only become significant in model (3a) and model (4a), but also improve their influence coefficients. This indicates that imposing strict environmental regulations to FDI can effectively avoid the 'race to the bottom' behavior when attracting foreign investment and induce green technology innovation and promote green productivity [46].

As for other control variables, $R \& D$ investment $(\ln R D)$ has a positive impact on industrial green total factor productivity, but it is only significant in the model of labor-based FDI. A possible reason is that labor-based FDI does not directly contribute to the green productivity, but rather transfers technology through training employees in the host country. This thereby enables technology spillovers through employee turnover [21,47]. Moreover, the coefficient of foreign trade (lnExout) is differs from that in Rubashkina et al. [45]. This is probably because the green total factor productivity in this paper considers environmental factors. This also implies that China's environmental regulation intensity is still weaker than that of developed countries. This leads to a comparative advantage of exporting industrial products, which is not conducive to the improvement of the national total factor productivity. Energy production efficiency $(\operatorname{lnEP})$ shows a significant positive impact in all models, consistent with Hu et al. [3]. This indicates that energy efficiency is also the driving force to promote industrial competitiveness.

\subsection{Threshold Effect Test}

This paper uses the software package MATLAB 2015b to detect the existence of threshold effect. In order to avoid the interference of extreme values, we ignore the $5 \%$ observations before and after. The threshold estimation is done according to the principle of minimum sum of squares of residuals. Then the self-sampling simulation likelihood ratio (LR) test statistic and critical value are used (Bootstrap 500 times) to check if there is a threshold effect. Table 3 shows the threshold estimation tests and results. It can be seen from Table 3 that the impact of labor-based FDI on green total factor productivity has a double-threshold effect. Similarly, capital-based FDI also has double threshold for environmental regulation intensity.

Table 3. Threshold value estimation results in the static panel model.

\begin{tabular}{ccccccc}
\hline $\begin{array}{c}\text { Threshold } \\
\text { Variable }\end{array}$ & $\begin{array}{c}\text { H0: LINEAR } \\
\text { Model (LR-Test) }\end{array}$ & $\begin{array}{c}\text { H0: SINGLE } \\
\text { Threshold (LR-Test) }\end{array}$ & $\begin{array}{c}\text { H0: Double } \\
\text { Threshold (LR-Test) }\end{array}$ & Threshold 1 & Threshold 2 & Threshold 3 \\
\hline lnFDIl & 34.61 & 22.32 & 10.11 & $2.49^{* * *}$ & $2.70^{* * *}$ \\
lnFDIk & 19.73 & 39.17 & 10.02 & $2.49^{* *}$ & $2.67^{* * *}$ & 3.28 \\
\hline
\end{tabular}

Note: Among them: ${ }^{* *}{ }^{* * *}$ respectively indicate that the parameters are estimated to pass the statistical significance test at $5 \%$, and $1 \%$. 
Table 4 summarizes the regression results of the threshold effect of labor-based FDI on green total factor productivity. From model (1b), under the low-intensity environment regulation, the impact coefficient of labor-based FDI on green total factor productivity is negative. In model (2b), capital-based FDI has a positive impact on green total factor productivity, but it is not significant at the $10 \%$ significance level. This shows that FDI's green technology spillover effect is affected by the environmental regulation intensity of the host country in addition to its own factor structure. When the environmental regulation intensity is medium, both types of FDI have a significant negative impact on green total factor productivity. It shows that when environmental regulation intensity is medium, it is not only unable to stimulate FDI to generate the green technology spillover effect, but also may induce foreign capital to compensate for the cost of production and increase the production of polluting products. This can further amplify the 'pollution haven' effect. However, with high intensity of environmental regulation, the coefficients of the spillover effects of the two types of FDI become positive. This is because strict environmental regulation can help adjust the structure of foreign capital, increase the environmental threshold for foreign investment, and play a 'screening' role for FDI.

Table 4. Estimation results from the static panel threshold model.

\begin{tabular}{ccc}
\hline \multirow{2}{*}{ Variable } & Labor-Based FDI & Capital-Based FDI \\
\cline { 2 - 3 } & $\mathbf{( 1 b )}$ & $\mathbf{( 2 b )}$ \\
\hline Regime 1 & -0.0026 & 0.0136 \\
& $(-0.282)$ & $(1.55)$ \\
Regime 2 & $-0.1023^{* * *}$ & $-0.1369^{* * *}$ \\
& $(-9.185)$ & $(-10.18)$ \\
Regime 3 & 0.0119 & $0.025^{* *}$ \\
& $(1.14)$ & $(2.4)$ \\
Sample & 468 & 468 \\
$R^{2}$ & 0.0748 & 0.0922 \\
\hline
\end{tabular}

Note: The value in parentheses is the value of $t$. Among them: ${ }^{* *}$ and ${ }^{* * *}$ respectively indicate that the parameters are estimated to pass the statistical significance test at $5 \%$ and $1 \%$.

It is worth noting that with high-intensity environmental regulation, only the coefficient of capital-based FDI is significant, consistent with Hu et al. [3]. Although labor-based FDI can lead to cleaner production, its inflow into China is mainly for cheaper labor capital. Most of the industries invested are in the supply chain stages with less value-adding activities. This is unfavorable to the green total factor productivity. With tighter environmental regulation, to reduce pollution, labor-based FDI needs to divert the elements (labor, capital, etc.) originally used for productive activities to non-productive activities [48]. This can help the adoption of green technologies in enterprises [49]. However, due to the required investment cost of environmental protection equipment and possible mismatch between the existing production materials with the new production equipment, it can eventually lower productivity [17]. On the other hand, capital-based FDI is mainly involved in the host country in the form of capital, aiming for a high return on capital. In the process of industrialization in developing countries, there is often a shortage of funds. This can lead to the inability of capital-intensive industries to purchase machinery with high environmental performance. The inflow of capital-based FDI not only provides the funds for equipment upgrading, but also promotes the technological level of domestic enterprises in the host country through 'demonstration effect' and 'learning effect' [50]. The coefficients of other control variables are also similar to the estimates in the linear model.

\subsection{Robust Regress}

In order to ensure our empirical results obtained so far are robust, this paper expands the static panel threshold model into a dynamic panel threshold model as detailed in Caner and Hansen [51] and Kremer et al. [52]. However, unlike Kremer et al. [52], this paper combines the modeling method of Hansen [37] to further expand the "single-threshold and dual-regime" model into a model that 
can estimate "multi-threshold and multi-regime" model. In this way, it is possible to more accurately detect the impact of environmental regulation intensity on the green technology spillover effect of FDI. The dynamic panel threshold value estimation and test results are shown in Table 5.

Table 5. Threshold value estimation results from the dynamic panel model.

\begin{tabular}{ccccccc}
\hline $\begin{array}{c}\text { Threshold } \\
\text { Variable }\end{array}$ & $\begin{array}{c}\text { H0: Linear } \\
\text { Model } \\
\text { (LR-Test) }\end{array}$ & $\begin{array}{c}\text { H0: Single } \\
\text { Threshold } \\
\text { (LR-Test) }\end{array}$ & $\begin{array}{c}\text { H0: Double } \\
\text { Threshold } \\
\text { (LR-Test) }\end{array}$ & $\begin{array}{c}\text { Threshold } \\
\text { Value 1 }\end{array}$ & $\begin{array}{c}\text { Threshold } \\
\text { Value 2 }\end{array}$ & $\begin{array}{c}\text { Threshold } \\
\text { Value 3 }\end{array}$ \\
\hline lnFDIl & 19.27 & 26.38 & 15.10 & $2.52^{* * *}$ & $2.73^{* * *}$ & $3.28^{*}$ \\
lnFDIk & 15.44 & 12.46 & 24.68 & $0.05^{* *}$ & $0.96^{*}$ & $3.28^{* * *}$ \\
\hline
\end{tabular}

Note: Among them: ${ }^{*}{ }^{* *},{ }^{* * *}$ respectively indicate that the parameters are estimated to pass the statistical significance test at $10 \%, 5 \%$, and $1 \%$.

According to the LR-test results based on the Bootstrap 500 times, there is a triple environmental regulation threshold effect whether the lnFDI1 or lnFDIk is the threshold variable, and the threshold of lnFDIl is very close to that in the static panel threshold model. This proves that the threshold estimate of lnFDIl is robust. However, the first two thresholds of lnFDIk are much smaller than the previous threshold. This may mean that the estimation result of lnFDIk in the static panel threshold model is not robust.

Table 6 shows the estimation results of the dynamic panel threshold model. The model (1c) and the model (2c) correspond to the estimation results of the labor-based FDI and the capital-based FDI as the threshold variable, respectively. Due to space limit, only the GMM estimation results of the $\ln G M L_{t-1}$ and threshold variables are listed in the table.

Table 6. Estimation results from the dynamic panel threshold model.

\begin{tabular}{ccc}
\hline \multirow{2}{*}{ Variable } & Labor-Based FDI & Capital-Based FDI \\
\cline { 2 - 3 } & $\mathbf{( 1 c )}$ & $\mathbf{( 2 c )}$ \\
\hline $\ln G M L_{t-1}$ & $-1.7009^{*}$ & $-1.389 *$ \\
& $(-2.13)$ & $(-1.85)$ \\
Regime 1 & -0.0141 & $-0.1013^{* * *}$ \\
& $(-1.42)$ & $(-7.45)$ \\
Regime 2 & $-0.0916^{* * *}$ & 0.0009 \\
& $(-6.80)$ & $(0.12)$ \\
Regime 3 & $-0.0204^{*}$ & $-0.0558^{* * *}$ \\
& $(-1.88)$ & $(-4.35)$ \\
Regime 4 & $0.0614^{* * *}$ & $0.0465 * * *$ \\
& $(3.72)$ & $(3.27)$ \\
Sample & 468 & 468 \\
Hansen J Statistic & 1.32 & 1.66 \\
$R^{2}$ & 0.1008 & 0.0916
\end{tabular}

Note: The value in parentheses is the value of $t$. Among them: ${ }^{*}$ and ${ }^{* * *}$ respectively indicate that the parameters are estimated to pass the statistical significance test at $10 \%$ and $1 \%$.

From model (1c) and model (2c), the coefficients of $\ln G M L_{t-1}$ are negative and significant at the $10 \%$ significance level, indicating that the green total factor productivity of the previous period has a negative impact on the current green total factor productivity. This is because technology has positive externalities and 'quasi-public goods' nature. Once invented, it is difficult to prevent other manufacturers from adopting this new technology [53], although green technology spillover benefits the overall pollution reduction of the industry. The associated 'free-riding' behavior can reduce the incentives for original green technology innovation. In terms of the coefficient of threshold value, the environmental regulation threshold effect of labor-based FDI and capital-based FDI green technology spillovers will exceed the third threshold (3.28). This is larger than that in the static panel 
threshold. This implies to induce FDI's green technology spillover, environmental regulation should be intensified. Finally, in the dynamic panel threshold model, the saliency of the coefficients of the individual control variables is different from that of the static model. This again confirms that the empirical results obtained in this paper are robust.

\section{Conclusions}

Many scholars have conducted in-depth studies on the relationships among heterogeneous FDI, environmental regulation, and green total factor productivity. However, there is no research on how heterogeneous types of FDI can generate technology spillover under different levels of environmental regulation intensity. To address this research gap, in this paper we use chemical oxygen demand, ammonia nitrogen, and $\mathrm{SO}_{2}$ and smoke (powder) dust emissions as unexpected output. We use SBM function and Global Malmquist-Luenberger (GML) index to calculate the green total factor productivity. Furthermore, combining static linear panel model, static panel threshold model and dynamic panel threshold model, we investigate the environmental regulatory threshold effect of labor-based FDI and capital-based FDI in terms of their green technology spillover. Our major findings include the following. Based on the static linear model, environmental regulation has significant and positive relationship with the green technology spillover of capital-based FDI. However, no such significant relationship is found for labor-based FDI. Based on the static threshold model, FDI's green technology spillover has double thresholds in terms of environmental regulation intensity. When the intensity is lower than a threshold, only capital-based FDI results in green technology spillover. When the environmental regulation intensity is between the first threshold and a second threshold, the green technology spillover effects of both types of FDI are significantly negative. When the environmental regulation intensity exceeds the second threshold, the green technology spillover effects of the two types of FDI become positive. Nonetheless, only the coefficient of capital-based FDI is significant. Finally, we employ the dynamic panel model for robustness check of our empirical results. The results show that to induce the two types of FDI to generate green technology spillover, it is necessary to continue to increase the environmental regulation intensity to the third threshold. Therefore, whether FDI can generate the green technology spillover effect and its direction is indeed affected by the host country's environmental regulation intensity.

The policy implications of this research are significant. There is a delicate balance between foreign investment, economic development, and the environment. On the one hand, in the early stage of economic development, developing countries can attract various types of foreign investment through preferential policies including lower environmental regulation. However, this kind of economic development at the expense of the ecological environment is unsustainable. On the other hand, after the economic development reaches a certain level, it is necessary to focus on the coordinated development of economic development and environment protection. This can be done by gradually tightening environmental regulations and screening and inducing FDI to result in green technology spillover. Therefore, it will be beneficial to establish and improve the screening mechanism of FDI enterprise, shifting the focus from FDI scale to FDI quality. The green technology spillover effect of high-quality FDI enterprises should be pursued for industry upgrading. Finally, environmental regulations should be designed and implemented considering different characteristics of FDI.

Author Contributions: J.H. and Z.W. conceived and designed the research question. J.H. constructed the models and analyzed the optimal solutions. J.H. and X.Z. wrote the paper. Q.H. reviewed and edited the manuscript. All authors read and approved the manuscript.

Funding: This research is supported by the National Natural Science Foundation of China, grant number 71473295, the National Social Science Foundation of China, grant number 17BJY060, the Social Science Planning Key Think Tank Foundation of Chongqing, grant number 2018ZDZK09, the Central University Innovation Team Foundation of Southwest University, grant number SWU1709108, and the Central University Major Nurturing Foundation of Southwest University, grant number SWU1809014.

Acknowledgments: The authors are grateful to the anonymous referees who provided valuable comments and suggestions to significantly improve the quality of the paper. 
Conflicts of Interest: The authors declare no conflict of interest. There is no professional or other personal interest of any nature or kind in any product, service, and/or company that could be construed as influencing the position presented in, or the review of, the manuscript entitled.

\section{References}

1. Wang, D.T.; Chen, W.Y. Foreign direct investment, institutional development, and environmental externalities: Evidence from China. J. Environ. Manag. 2014, 135, 81-90. [CrossRef] [PubMed]

2. Chen, Q.; Min, M.; Shi, Y.; Wilson, C. Foreign direct investment concessions and environmental levies in China. Int. Rev. Financ. Anal. 2014, 36, 241-250. [CrossRef]

3. Hu, J.; Wang, Z.; Lian, Y.; Huang, Q. Environmental Regulation, Foreign Direct Investment and Green Technological Progress-Evidence from Chinese Manufacturing Industries. Int. J. Environ. Res. Public Health 2018, 15, 221. [CrossRef]

4. Yoon, H.; Heshmati, A. Do Environmental Regulations Effect FDI Decisions? The Pollution Haven Hypothesis Revisited; Social Science Electronic Publishing: Rochester, NY, USA, 2017; pp. 1-24.

5. Chung, S. Environmental regulation and foreign direct investment: Evidence from South Korea. J. Dev. Econ. 2014, 108, 222-236. [CrossRef]

6. Acharyya, J. FDI, growth and the environment: Evidence from India on $\mathrm{CO}_{2}$ emission during the last two decades. J. Econ. Dev. 2009, 34, 43-58.

7. Dean, J.M. Does trade liberalization harm the environment? A new test. Can. J. Econ. 2002, 35, 819-842. [CrossRef]

8. Song, M.; Tao, J.; Wang, S. FDI, technology spillovers and green innovation in China: Analysis based on Data Envelopment Analysis. Ann. Oper. Res. 2015, 228, 47-64. [CrossRef]

9. Stewart, R.B. Pyramids of Sacrifice? Problems of Federalism in Mandating State Implementation of National Environmental Policy. Yale Law J. 1977, 86, 1196-1272. [CrossRef]

10. Woods, N.D. Interstate Competition and Environmental Regulation: A Test of the Race-to-the-Bottom Thesis. Soc. Sci. Q. 2006, 87, 174-189. [CrossRef]

11. Taylor, M.S. Unbundling the Pollution Haven Hypothesis. Adv. Econ. Anal. Policy 2004, 3, 1-28. [CrossRef]

12. Cole, M.A.; Elliott, R.J.R. FDI and the Capital Intensity of "Dirty" Sectors: A Missing Piece of the Pollution Haven Puzzle. Rev. Dev. Econ. 2005, 9, 530-548. [CrossRef]

13. Cai, X.; Lu, Y.; Wu, M.; Yu, L. Does environmental regulation drive away inbound foreign direct investment? Evidence from a quasi-natural experiment in China. J. Dev. Econ. 2016, 123, 73-85. [CrossRef]

14. Chudnovsky, D.; Pupato, G. Environmental Management and Innovation in Argentine Industry; CENIT: Buenos Aires, Argentina, 2005.

15. Birdsall, N.; Wheeler, D. Trade Policy and Industrial Pollution in Latin America: Where Are the Pollution Havens? J. Environ. Dev. 1993, 2, 137-149. [CrossRef]

16. Tang, J. Testing the Pollution Haven Effect: Does the Type of FDI Matter? Environ. Resour. Econ. 2015, 60, 549-578. [CrossRef]

17. Hancevic, P.I. Environmental regulation and productivity: The case of electricity generation under the CAAA-1990. Energy Econ. 2016, 60, 131-143. [CrossRef]

18. Johnstone, N.; Managi, S.; Rodríguez, M.C.; Haščič, I.; Fujii, H.; Souchier, M. Environmental policy design, innovation and efficiency gains in electricity generation. Energy Econ. 2017, 63, 106-115. [CrossRef]

19. Wang, Y.; Shen, N. Environmental regulation and environmental productivity: The case of China. Renew. Sustain. Energy Rev. 2016, 62, 758-766. [CrossRef]

20. Xie, R.H.; Yuan, Y.J.; Huang, J.J. Different Types of Environmental Regulations and Heterogeneous Influence on "Green" Productivity: Evidence from China. Ecol. Econ. 2017, 132, 104-112. [CrossRef]

21. Lin, P.; Liu, Z.; Zhang, Y. Do Chinese domestic firms benefit from FDI inflow?: Evidence of horizontal and vertical spillovers. China Econ. Rev. 2009, 20, 677-691. [CrossRef]

22. Dean, J.M.; Lovely, M.E.; Wang, H. Are foreign investors attracted to weak environmental regulations? Evaluating the evidence from China. J. Dev. Econ. 2009, 90, 1-13. [CrossRef]

23. Markusen, J.R.; Venables, A.J. Multinational Firms and the New Trade Theory; NBER Working Papers; NBER: Cambridge, MA, USA, 1995; Volume 46, pp. 183-203. [CrossRef] 
24. Javorcik, B.S.; Spatareanu, M. To share or not to share: Does local participation matter for spillovers from foreign direct investment? J. Dev. Econ. 2008, 85, 194-217. [CrossRef]

25. Liang, F.H. Does foreign direct investment improve the productivity of domestic firms? Technology spillovers, industry linkages, and firm capabilities. Res. Policy 2017, 46, 138-159. [CrossRef]

26. Broner, F.; Bustos, P.; Carvalho, V.M. Sources of Comparative Advantage in Polluting Industries; Working Papers; NBER: Cambridge, MA, USA, 2012. [CrossRef]

27. Greaney, T.M.; Li, Y.; Tu, D. Pollution control and foreign firms' exit behavior in China. J. Asian Econ. 2017, 48, 148-159. [CrossRef]

28. Cole, M.A.; Elliott, R.J.R. Do Environmental Regulations Influence Trade Patterns? Testing Old and New Trade Theories. World Econ. 2003, 26, 1163-1186. [CrossRef]

29. Antonietti, R.; De Marchi, V.; Di Maria, E. Governing offshoring in a stringent environmental policy setting: Evidence from Italian manufacturing firms. J. Clean. Prod. 2017, 155, 103-113. [CrossRef]

30. Zugravu-Soilita, N. How does Foreign Direct Investment Affect Pollution? Toward a Better Understanding of the Direct and Conditional Effects. Environ. Resour. Econ. 2015, 66, 293-338. [CrossRef]

31. Elliott, R.J.R.; Zhou, Y. Environmental Regulation Induced Foreign Direct Investment. Environ. Resour. Econ. 2013, 55, 141-158. [CrossRef]

32. Acemoglu, D.; Aghion, P.; Bursztyn, L.; Hemous, D. The Environment and Directed Technical Change. Am. Econ. Rev. 2012, 102, 131-166. [CrossRef]

33. Javorcik, B.S.; Spatareanu, M. Does it matter where you come from? Vertical spillovers from foreign direct investment and the origin of investors. J. Dev. Econ. 2011, 96, 126-138. [CrossRef]

34. Oh, D.H. A global Malmquist-Luenberger productivity index. J. Prod. Anal. 2010, 34, 183-197. [CrossRef]

35. Bretschger, L.; Lechthaler, F.; Rausch, S.; Zhang, L. Knowledge Diffusion, Endogenous Growth, and the Costs of Global Climate Policy. Eur. Econ. Rev. 2017, 93, 47-72. [CrossRef]

36. Aldieri, L.; Kotsemir, M.N.; Vinci, C.P. Knowledge spillover effects: Empirical evidence from Russian regions. Qual. Quant. 2017, 1-22. [CrossRef]

37. Hansen, B.E. Threshold effects in non-dynamic panels: Estimation, testing, and inference. J. Econom. 1999, 93, 345-368. [CrossRef]

38. Fukuyama, H.; Weber, W.L. A Directional Slacks-Based Measure of Technical Efficiency. Socio-Econ. Plan. Sci. 2009, 43, 274-287. [CrossRef]

39. Zhao, X.; Liu, C.; Yang, M. The effects of environmental regulation on China's total factor productivity: An empirical study of carbon-intensive industries. J. Clean. Prod. 2018, 179, 325-334. [CrossRef]

40. Lucchesi, A.; Cole, M.A.; Elliot, R.J.R.; Menezesfilho, N.A. Determinants of Environmental Innovation in Brazilian Manufacturing Industries. In Proceedings of the 42nd Brazilian Economics Meeting, Natal, Brazil, 9 December 2014.

41. Guo, Y.; Xia, X.; Zhang, S.; Zhang, D. Environmental Regulation, Government R\&D Funding and Green Technology Innovation: Evidence from China Provincial Data. Sustainabilaty 2018, 10, 940. [CrossRef]

42. Kumar, S.; Managi, S. Environmental Productivity and Kuznets Curve. Ecol. Econ. 2008, 65, 432-440. [CrossRef]

43. Beugelsdijk, S.; Smeets, R.; Zwinkels, R. The impact of horizontal and vertical FDI on host's country economic growth. Int. Bus. Rev. 2008, 17, 452-472. [CrossRef]

44. Albrizio, S.; Koźluk, T.; Zipperer, V. Environmental Policies and Productivity Growth: Evidence Across Industries and Firms. J. Environ. Econ. Manag. 2016, 81, 209-226. [CrossRef]

45. Rubashkina, Y.; Galeotti, M.; Verdolini, E. Environmental regulation and competitiveness: Empirical evidence on the Porter Hypothesis from European manufacturing sectors. Energy Policy 2015, 83, 288-300. [CrossRef]

46. Porter, M.E.; Van der Linde, C. Toward a New Conception of the Environment-Competitiveness Relationship. J. Econ. Perspect. 1995, 9, 97-118. [CrossRef]

47. Fosfuri, A.; Motta, M.; Rønde, T. Foreign direct investment and spillovers through workers' mobility. J. Int. Econ. 2001, 53, 205-222. [CrossRef]

48. Ambec, S.; Cohen, M.A.; Elgie, S.; Lanoie, P. The Porter Hypothesis at 20: Can Environmental Regulation Enhance Innovation and Competitiveness? Rev. Environ. Econ. Policy 2013, 7, 2-22. [CrossRef]

49. Nesta, L.; Vona, F.; Nicolli, F. Environmental policies, competition and innovation in renewable energy. J. Environ. Econ. Manag. 2014, 67,396-411. [CrossRef] 
50. Zhang, Y.; Na, S.; Niu, J.; Jiang, B. The Influencing Factors, Regional Difference and Temporal Variation of Industrial Technology Innovation: Evidence with the FOA-GRNN Model. Sustainability 2018, 10, 187. [CrossRef]

51. Caner, M.; Hansen, B.E. Instrumental variable estimation of a threshold model. Econ. Theory 2004, 20, 813-843. [CrossRef]

52. Kremer, S.; Bick, A.; Nautz, D. Inflation and growth: New evidence from a dynamic panel threshold analysis. Empir. Econ. 2013, 44, 861-878. [CrossRef]

53. Macho-Stadler, I.; Pérez-Castrillo, D. Optimal enforcement policy and firms' emissions and compliance with environmental taxes. J. Environ. Econ. Manag. 2006, 51, 110-131. [CrossRef]

(C) 2019 by the authors. Licensee MDPI, Basel, Switzerland. This article is an open access article distributed under the terms and conditions of the Creative Commons Attribution (CC BY) license (http://creativecommons.org/licenses/by/4.0/). 